\title{
Results of satellite tagging of Atlantic bluefin tuna, Thunnus thynnus, off the coast of Ireland
}

\author{
Michael J. W. Stokesbury • Ronan Cosgrove • \\ Andre Boustany · Daragh Browne • \\ Steven L. H. Teo · Ronald K. O'Dor • \\ Barbara A. Block
}

(C) Springer Science+Business Media B.V. 2007

\begin{abstract}
Pop-up satellite archival tags were attached to six Atlantic bluefin tuna (Thunnus thynnus) off the west coast of Ireland in autumn 2003 and 2004. The satellite tags measured pressure, ambient temperature and light for the term of deployment. Radio pop-up satellite endpoint positions, light and sea surface temperature estimations of geolocation indicate that two fish tagged minutes apart off the coast of County Donegal, migrated to the eastern and western Atlantic Ocean over the following 8 months. The two fish were $5218 \mathrm{~km}$ apart at the termination of the experiment. After tagging in September and popping up the following March and April, one
\end{abstract}

Guest editors: P. R. Almeida, B. R. Quintella, M. J. Costa and A. Moore Developments in Fish Telemetry

M. J. W. Stokesbury $(\bowtie) \cdot$ R. K. O’Dor

Biology Department, Dalhousie University, 1355

Oxford St., Halifax, Nova Scotia, Canada B3H 4J1

e-mail: mstokesb@dal.ca

M. J. W. Stokesbury · A. Boustany .

S. L. H. Teo · B. A. Block

Tuna Research and Conservation Center, Stanford University, Hopkins Marine Station, Oceanview

Boulevard, Pacific Grove, CA 93950, USA

R. Cosgrove $\cdot$ D. Browne

An Bord Iascaigh Mhara (BIM), The Irish Sea

Fisheries Board, New Docks, Co. Galway, Ireland fish had traveled to the western Atlantic while the other was located in the waters off the southwest coast of Portugal. A third fish tagged off the coast of County Donegal in October 2004 moved into the Mediterranean Sea and was caught by a fishing vessel southeast of Malta on 11 June 2005. The results link bluefin tuna feeding on European foraging grounds with known eastern breeding regions and western Atlantic waters.

Keywords Bluefin tuna - Ireland .

Satellite tags $\cdot$ Movement

\section{Introduction}

The study of fish migration and stock identification are closely related (Mather et al., 1995). Tagging studies initiated in the western Atlantic Ocean and using Pop-up Satellite Archival Transmitting Tags (PATs) and implantable archival tags have investigated the movement patterns of Atlantic bluefin tuna (Thunnus thynnus L.; Block et al., 2001; Stokesbury et al., 2004; Block et al., 2005; Wilson et al., 2005). Bluefin tuna are commercially important, highly migratory members of the scombridae. Their migration patterns and stock structure is complex (Mather, 1995, Block et al., 2001; 2005) and understanding their movement patterns is crucial for their proper management and conservation (NRC 1994). 
Fisheries for Atlantic bluefin tuna are managed by the International Commission for the Conservation of Atlantic Tunas (ICCAT) under a two stock hypothesis (NRC, 1994). One eastern Atlantic Ocean and Mediterranean Sea stock that spawns in the Mediterranean Sea (Richards, 1976) and another western Atlantic Ocean stock that spawns in the Gulf of Mexico (McGowan and Richards, 1989) and the Florida Straits (Rivas, 1954). The stock boundary line used by ICCAT to divide the stocks is at $45 \mathrm{~W}$ Longitude. Bluefin tuna are managed as if there is a low mixing rate ( 2-4\% year $^{-1}$ NRC, 1994) between the two stocks. However, a recent electronic tagging study indicated that the trans-Atlantic movement rate of bluefin tuna was likely to be higher because $37.2 \%$ of the recaptures of Atlantic bluefin that were tagged in the western Atlantic Ocean, occurred in the eastern Atlantic Ocean and Mediterranean Sea (Block et al., 2005). The electronic tagging in western Atlantic locations suggests that a significant component from the eastern spawned stock must migrate into west Atlantic waters for foraging. Similarly, some large giants from the Gulf of Mexico spawned stock, migrate into central and East Atlantic waters to forage. Discerning the extent of this mixing, and the affect this has on the assessment of abundance of each stock, is critical to the future management of Atlantic bluefin tuna.

In 2000, a small sport fishery for Atlantic bluefin tuna began off the coast of County Donegal and more recently one has also begun off County Mayo, on the mid-west coast of Ireland. Little is known about the life history of the giant bluefin tuna now being targeted by sports fishers in these fisheries. Bluefin tuna that enter Norwegian waters most likely traveled through the waters off the northwest coast of Ireland (Mather et al., 1995). Also, fish may pass western Ireland on route from waters in the western Atlantic, to the spawning grounds in the Mediterranean Sea (Mather et al., 1995). Interestingly, bluefin tuna present off Norway in the autumn have also been linked to the Western Atlantic Ocean as nine large bluefin tuna tagged in the Bahamas were captured off Norway (Mason et al., 1977). Also, recent electronic tagging experiments indicated that some bluefin tuna tagged off the coast of North Carolina in winter moved in spring and summer months to the Eastern Atlantic Ocean and to the waters offshore of Ireland (Block et al., 2005). Some of these fish continued on into the Mediterranean Sea to spawn indicating that eastern stock fish were foraging in the west and east Atlantic.

The migration pattern and stock of origin of the Atlantic bluefin tuna currently being exploited off the west coast of Ireland is unknown. In this study we employed the PAT tags and external tagging methodologies used in the western Atlantic Ocean (Block et al., 2001), to tag giant bluefin tuna captured in the eastern Atlantic Ocean. The study enabled the examination of movements and environmental preferences of several individuals of giant bluefin tuna released off the west coast of Ireland.

\section{Materials and methods}

Atlantic bluefin tuna were fished in two different locations off the west coast of Ireland. Fish were captured by trolling squid spreader bars with rod and reel off County Donegal and County Mayo. The fish were caught and brought on board the tagging vessel, measured, and tagged with PATs using procedures described by Stokesbury et al., (2004). The PATs (hardware PAT4, software $4.01 \mathrm{e}$ ) provided an end point location based on the Doppler shift of the tags radio transmission to the Argos satellites (root mean square error of $<350 \mathrm{~m}$; Taillade, 1992). PATs also measured and archived light, ambient temperature and pressure at $60 \mathrm{~s}$ intervals. Depth and temperature data were summarized into $12 \mathrm{~h}$ bins prior to transmission. Temperature vs. depth profiles were generated with minimum and maximum temperature at each of the eight equally spaced depths. The tags were equipped with a pre-release program and an auto-depth correction. So, if the tag prematurely detached from the fish and floated to the surface it reported to the satellite 4 days after detachment.

The daily movements of Atlantic bluefin tuna were estimated from light-based calculation of longitude using Wildlife Computers WC-GPE 1.01.0005 (Hill and Braun, 2001), and latitude estimates based on satellite derived sea surface 
temperatures (SST) at the derived longitude compared with SST's recorded by the tag (Teo et al., 2004). Geolocation estimates for PATs deployed on Atlantic bluefin tuna had a root mean square error of 1.30 for light-based longitude and 1.89 for SST-based latitude (Teo et al., 2004).

\section{Results}

A total of six Atlantic bluefin tuna were tagged and released with second generation PATs off the west coast of Ireland in 2003 and 2004. In 2003 two fish (221 and $225 \mathrm{~cm}$ curved fork length (CFL)) were tagged off County Donegal (55.36 N, 7.52 W) on 20 September, each with a single PAT tag (\#03-267 and 03-191, respectively) and an externally placed conventional tag. These two fish were hooked by the same boat at approximately the same time and were tagged and released within 15 min of each other. A third fish (264 cm CFL) was tagged off County Mayo on 15 October 2003 with PSAT \#03-275. The tags deployed on the two fish released off County Donegal reported 177 (PSAT \#03-267) and 205 (PSAT \#03-191) days later from different sides of the Atlantic Ocean. Tag \#03-275 failed to report. In 2004 two fish $(226$ and $230 \mathrm{~cm}$ curved fork length (CFL)) were tagged off County Donegal
$(55.43 \mathrm{~N}, 7.38 \mathrm{~W})$ on 9 October, each with a single PAT tag (\#04-267 and 04-268, respectively) and an externally placed conventional tag. These two fish were hooked by the same boat at approximately the same time and were tagged and released within 10 min of each other. A third fish (230 cm CFL) was tagged off County Donegal $(55.41 \mathrm{~N}, 7.46 \mathrm{~W})$ on 8 October 2004 with PSAT \#04-269. The tag deployed on the fish released off County Donegal on 8 October was later returned by fisherman after they caught the fish in the Mediterranean Sea on 11 June 2005. Tags \#04-267 and 04-268 failed to report.

Tag 03-267 reported to Argos satellites on 15 March 2004 from the Bahamas at $25.67 \mathrm{~N}$, $67.39 \mathrm{~W}$, a straight-line distance of $5805 \mathrm{~km}$ from the tagging site (Fig. 1). Geolocation positions indicate that this fish resided in waters over the Irish shelf from tagging until 26 October. It then moved to off shelf waters for a period of 24 days, corroborated by multiple dives to depths deeper than $400 \mathrm{~m}$ (Fig. 2a). The fish then returned to waters over the Irish shelf on 19 November 2004, where it remained until 18 December, 2004. It then again moved off shelf until the tag reported from the Bahamas in March, 2004 (Fig. 1).

Fish $03-267$ spent $79.9 \%$ of its time in the top $100 \mathrm{~m}$ of the water column including $42.8 \%$ in the top $5 \mathrm{~m}$ (Fig. 3a). The fish spent $55.5 \%$ of its time in water with temperatures between 12 and $16^{\circ} \mathrm{C}$

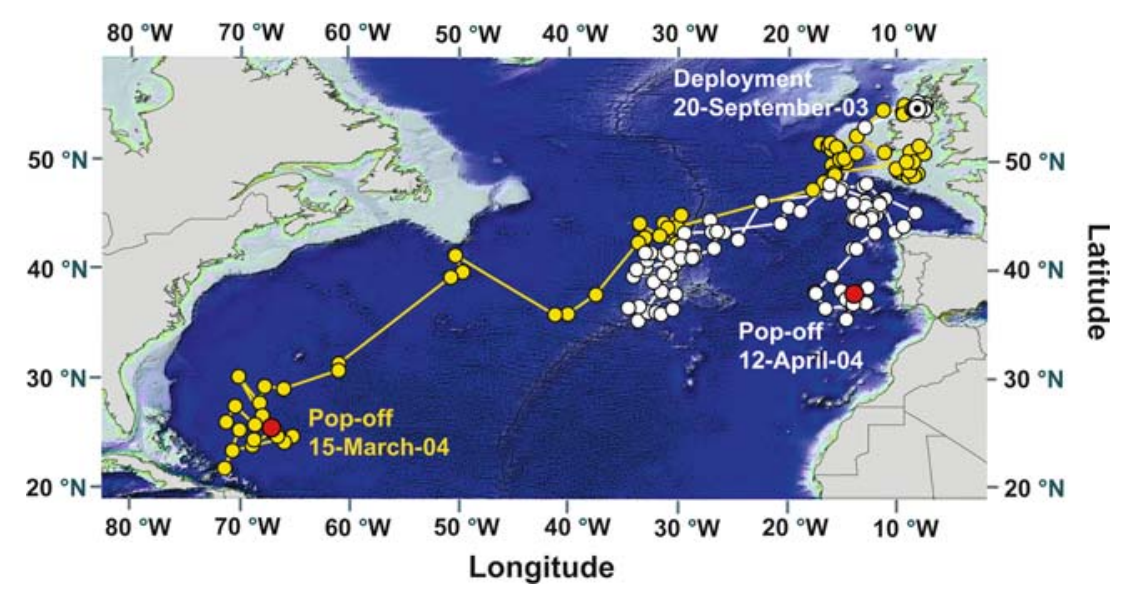

Fig. 1 Location data from pop-up satellite tags deployed on two Atlantic bluefin tuna (yellow circles = fish 03-267, white circles $=$ fish 03-191) off Ireland (circle with dot $=$ release location) in autumn 2003, obtained from radio transmission end points to the Argos satellite system (red circles), and geolocation estimates based on light level longitude and sea surface temperature latitude estimates (yellow and white circles; $N=184$ ) 
Fig. 2 Maximum depth $(\diamond)$, maximum $(\square)$ and minimum $(\Delta)$

temperatures reported by

PATs deployed on

Atlantic bluefin tuna: (a)

03-267 and (b) 03-191,

both tagged off the west

coast of Ireland in autumn

2003
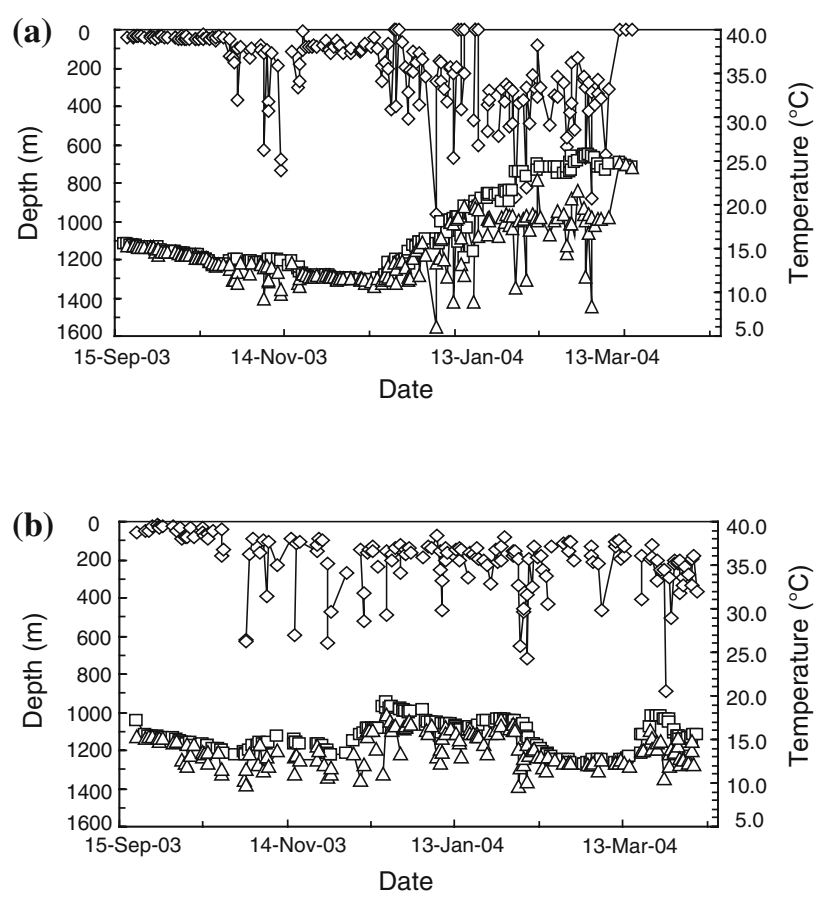

the tagging site (Fig. 1). Geolocation positions (Fig. 1) and its maximum depth profile (Fig. 2b) indicate that this fish resided in waters over the Irish shelf from tagging until 21 October, and then moved off shelf. It then moved off shelf to waters over the mid-Atlantic Ridge and back to the Eastern Atlantic Ocean. Finally the fish resided in
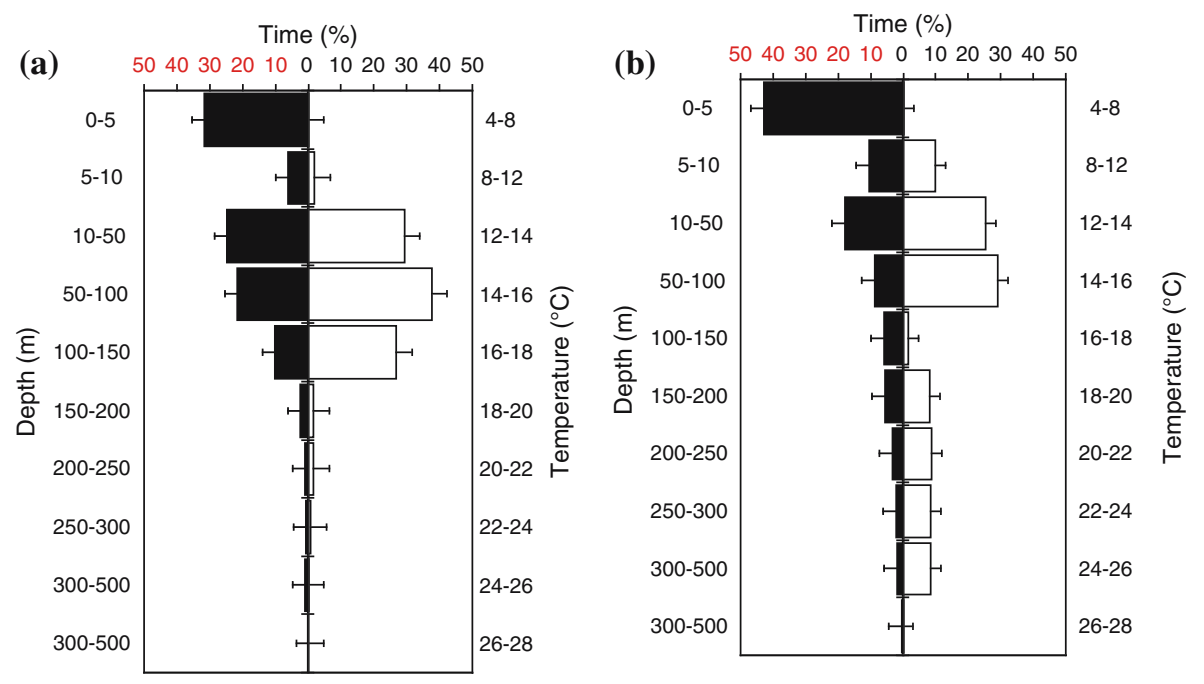

Fig. 3 Bluefin tuna (a) 03-267's and (b) 03-191's time at depth distribution (black) and time at temperature distribution (white) 
Fig. 4 Water column temperature profile generated by (a) tag 03267 and (b) tag 03-191
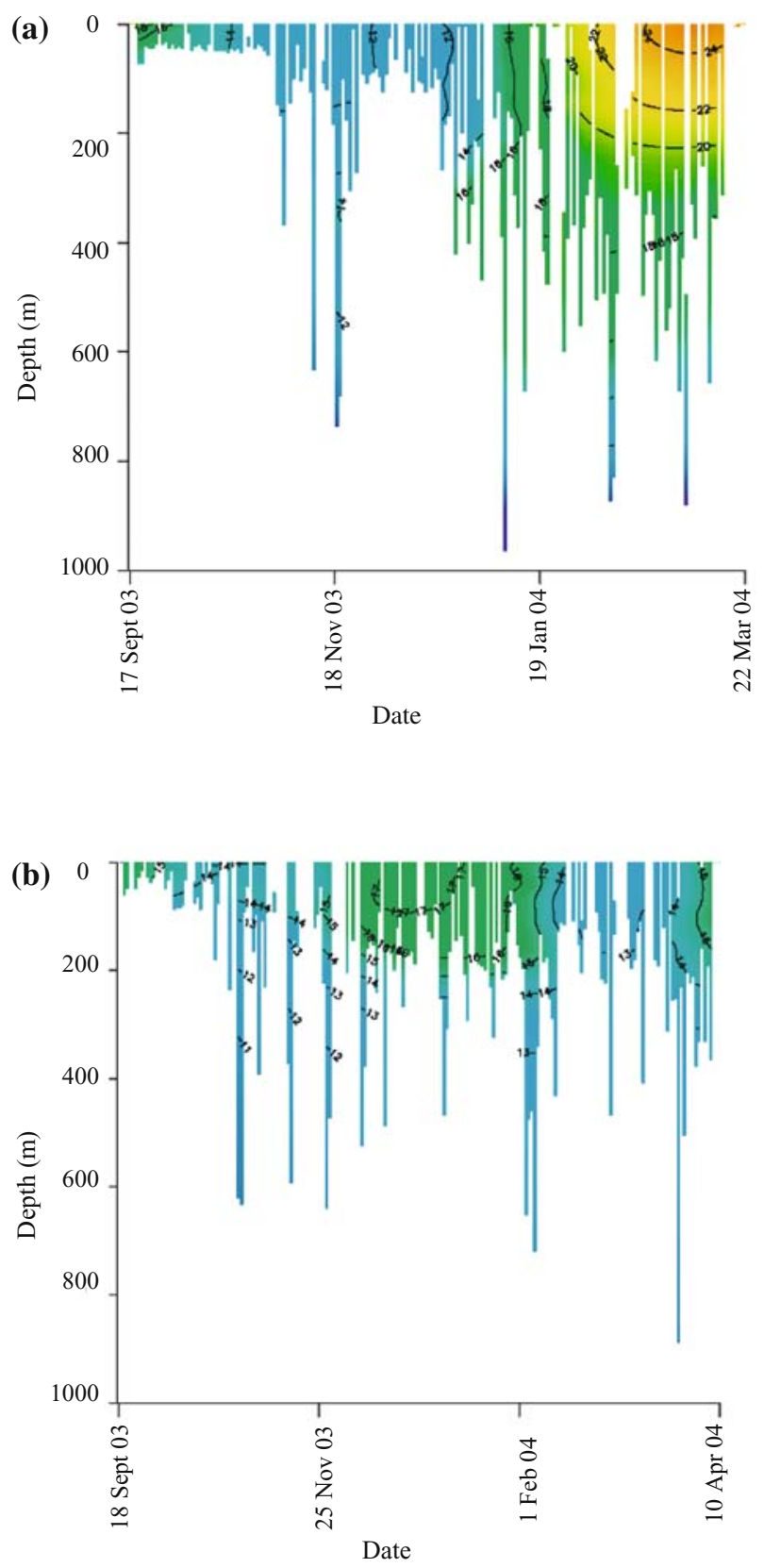

shelf waters, southwest of Portugal until the tag reported (Fig. 1).

Fish $03-191$ spent $84.25 \%$ of it's time in the top $100 \mathrm{~m}$ of the water column (Fig. 3b). The fish spent $93.84 \%$ it's time in water with temperatures between 12 and $18^{\circ} \mathrm{C}$ (Fig. 3b). The temperature depth profile indicated that the water column was mixed and cool during the period on the Irish shelf. However, when the fish moved to the midAtlantic Ocean, the water column became more stratified and the thermocline was deeper. Finally, off Portugal the water column again became mixed and cool (Fig. 4b).

Tag 04-269 was captured in a purse seine on 11 June 2005 in waters southwest of Malta, at $31.57 \mathrm{~N}, 17.42 \mathrm{~W}$, a straight-line distance of 
Fig. 5 Location data from a pop-up satellite tag deployed on an Atlantic bluefin tuna (04-269) off Ireland in autumn 2004, obtained from radio transmission end points to the Argos satellite system, and geolocation estimates based on light level longitude and sea surface temperature latitude estimates (circles are color coded for month)

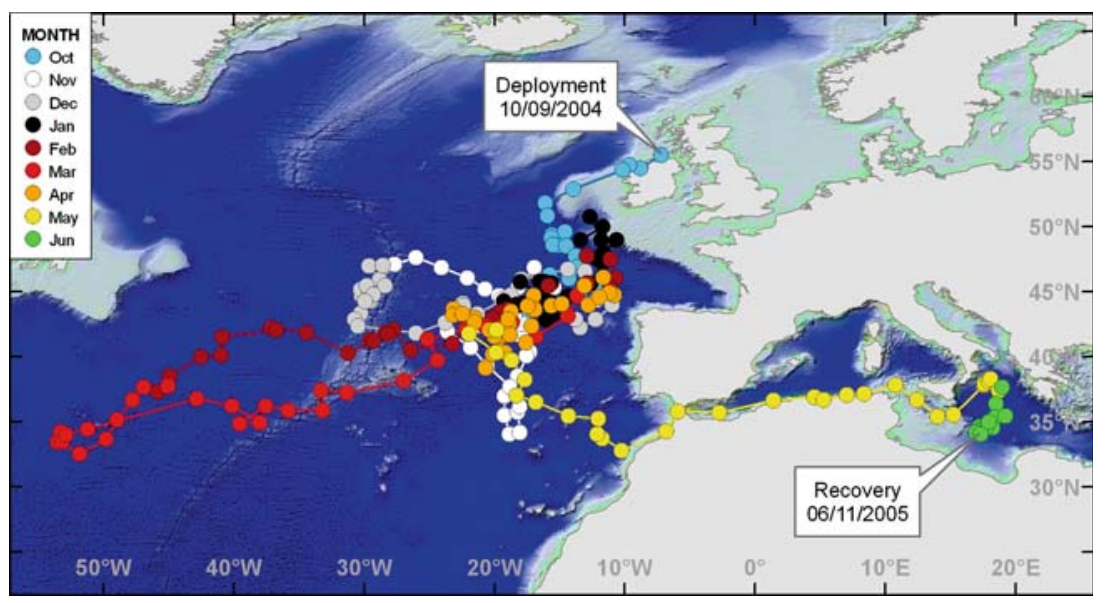

$2766 \mathrm{~km}$ from the tagging site (Fig. 5). Geolocation positions (Fig. 5) indicate that this fish moved southwest from waters off Ireland in October and remained in the North Atlantic until May 2005. The fish then crossed into the Mediterranean Sea in June 2005 and was captured by a purse seine fishing vessel 11 July 2005.

\section{Discussion}

Atlantic bluefin tuna caught and tagged on feeding grounds in waters off the northwest coast of Ireland in autumn 2003 and 2004 subsequently moved to waters in the West Atlantic Ocean and the Mediterranean Sea. These results link bluefin tuna feeding on European foraging grounds with known eastern breeding regions and western management zone waters

Two fish simultaneously caught and tagged at approximately the same time in September 2003 off the west coast of Ireland, moved to opposite sides of the Atlantic Ocean by March and April, 2004. Bluefin tuna 03-267 traveled to the waters of the Bahamas, close to the Florida Straits, a proposed spawning ground for bluefin tuna in the northwest Atlantic Ocean (Rivas, 1954). The water in this area was warm enough for a bluefin tuna to spawn $\left(>24^{\circ} \mathrm{C}\right.$; Block et al., 2001). Electronically tagged bluefin tuna from previous studies have moved to these waters in winter and spring and encountered ambient water temperatures warm enough to be indicative of spawning
(Block et al., 2001). This fish was tagged $2342 \mathrm{~km}$ east of the ICCAT stock boundary line, and moved to a Western Atlantic Ocean location, during the spawning season. Fish 03-191, traveled to waters off southwestern Portugal near the Ibero-Moroccan Bay. However, the water temperatures at the time the tag reported were well below the temperatures in which bluefin tuna are hypothesized to spawn (Block et al., 2001; 2005). The tag reported approximately $755 \mathrm{~km}$ from the Straits of Gibraltar. Possibly this fish was on its way to the Mediterranean spawning ground when the tag popped up.

Both fish spent a large portion of their time in the top $5 \mathrm{~m}$ of the water column. This may be due to the overall thermal regime that the fish are exposed to in the offshore waters off Ireland. Overall the temperatures were cool and the occupancy of surface waters may be associated with the thermal tolerances of both prey and giant bluefin. The tuna spent the majority of their time in a fairly narrow temperature range during the period they were in east Atlantic waters. However, the two temperature ranges differed significantly with fish 03-267 experiencing warmer and cooler time-at-temperature profiles than 03-191. This was caused by bluefin tuna 03-267 moving into the west Atlantic in winter where it encountered the warmer waters of the Bahamas while bluefin tuna 03-191 occupied the cooler waters of the mid and eastern Atlantic Ocean in winter.

Fish 04-269 traveled to waters southwest of Malta in the Mediterranean Sea in the months of 
May and June. This fish moved from the feeding grounds off northwestern Ireland to the spawning grounds in the Mediterranean Sea precisely during the time that other electronically tagged fish move into these regions from the west Atlantic releases (Block et al., 2001; 2005). This result suggests that at least a component of the Irish offshore fishery is composed of Mediterranean spawned breeders.

The results of this study are in agreement with previous studies showing linkages between Atlantic bluefin tuna off the coast of North America and those found off the coast of Ireland (Block et al., 2005), and also support a potential link between Atlantic bluefin tuna on the feeding grounds off Ireland and the eastern Atlantic Ocean spawning grounds off Malta in the Mediterranean Sea. Additionally linkage between the foraging grounds off Ireland and the west Atlantic spawning grounds is tentatively shown here however technically the position of the pop-up satellite tag was just to the North of the known ICCAT areas where bluefin are putatively thought to spawn in the west Atlantic outside the Gulf of Mexico. Given the small sample size, caution must be exercised in over interpreting these tracks. However they are similar to several tracks noted in Block et al. (2005), indicating potentially that independent breeding stocks are mixing on feeding grounds and then sorting to breeding grounds. It is important to increase the tagging effort in the eastern Atlantic Ocean to gain further knowledge of the movement patterns and stock structure of the autumn aggregation of bluefin tuna that is present off the west coast of Ireland.

Acknowledgements This study was supported by BIM, a grant from the David and Lucile Packard Foundation and the Monterey Bay Aquarium Foundation. MJWS was supported by a Dalhousie scholarship, and NSERC IPGS and an NSERC grant to RKO. We thank A. Malloy and J. Brittain, for vessel access that made this study possible, $\mathrm{H}$. Tan for logistical support, and A. Walli and K. Weng for help with figure preparation.

\section{References}

Block, B. A., H. Dewar, S. B. Blackwell, T. D. Williams, E. D. Prince, C. J. Farwell, A. Boustany, S. L. H. Teo, A.
Seitz, A. Walli \& D. Fudge, 2001. Migratory movements, depth preferences, and thermal biology of Atlantic bluefin tuna. Science 293: 1310-1314.

Block, B. A., S. L. H. Teo, A. Walli, A. Boustany, M. J. W. Stokesbury, C. Farwell, T. Williams, K. Weng \& H. Dewar, 2005. Electronic tagging and population structure of Atlantic bluefin tuna. Nature 434: 11211127.

Hill, R. D. \& M. J. Braun, 2001. Geolocation by light-level. The next step: latitude. In Sibert, J. \& J. Neilson (eds), Methods and Technologies in Fish Biology and Fisheries. Vol. 1. Kluwer Academic, Dordrecht, The Netherlands, 443-456.

Mason, J. M. Jr., F. J. III Mather \& R. E. Baglin Jr., 1977. Results of United States cooperative tagging of Atlantic bluefin tuna, October 1974 through October 1976. ICCAT, Collective Volume of Scientific Papers 6: 259-263.

Mather, F. J., J. M. Mason \& A. C. Jones, 1995. Historical document: life history and fisheries of Atlantic bluefin tuna. NOAA Technical Memorandum NMFS-SEFSC- 370, p. 165.

McGowan, M. F. \& W. J. Richards, 1989. Bluefin tuna, Thunnus thynnus, larvae in the Gulf Stream off the Southeastern United States: satellite and shipboard observations of their environment. Fisheries Bulletin 87: 613-631.

National Research Council, 1994. An assessment of Atlantic bluefin tuna. National Academy Press, Washington D.C, 143 pp.

Richards, W. J, 1976. Spawning of bluefin tuna (Thunnus thynnus) in the Atlantic Ocean and adjacent seas. ICCAT Collective Volume of Scientific Papers 2: 03267-278.

Rivas, L. R., 1954. A preliminary report on the spawning of the western north Atlantic bluefin tuna (Thunnus thynnus) in the Straits of Florida. Bulletin of Marine Science Gulf and Caribbean 4: 302-322.

Stokesbury, M. J. W., S. L. H. Teo, A. Seitz, R. K. O'Dor \& B. A. Block, 2004. Movement of Atlantic bluefin tuna (Thunnus thynnus) as determined by satellite tagging experiments initiated off New England. Canadian Journal of Fisheries and Aquatic Sciences 61: 1976-1987.

Taillade M., 1992. Animal tracking by satellite. In Priede, I. M. \& S. M. Swift (eds), Wildlife Telemetry Remote Monitoring and Tracking of Animals. Ellis Horwood, New York, NY. pp. 149-160.

Teo, S. L. H., A. Boustany, S. Blackwell, A. Walli, K. C. Weng \& B. A. Block, 2004. Validation of geolocation estimates based on light level and sea surface temperature from electronic tags. Marine Ecology Progress Series 283: 81-98.

Wilson, S. G., M. E. Lutcavage, R. W. Brill, M. P. Genovese, A. B. Cooper \& A. W. Everly, 2005. Movements of bluefin tuna (Thunnus thynnus) in the northwestern Atlantic Ocean recorded by pop-up satellite archival tags. Marine biology 146: 409-423. 